\title{
Basic $\mathrm{Al}_{2} \mathrm{O}_{3} / \mathrm{PCl}_{5}$ as an Efficient Reagent for the Direct Synthesis of Nitriles from Aldehydes under Solvent-Free Conditions
}

\author{
Khodabakhsh Niknam, Bahador Karami, ${ }^{\dagger}$ and Ali Reza Kiasat ${ }^{*}$ \\ Department of Chemistry, Faculty of Sciences, Persian Gulf University, Bushehr 75168, Iran \\ "E-mail:kh_niknam@yahoo.com; niknam@pgu.ac.ir \\ ${ }^{\dagger}$ Department of Chemistry, Yasouj University, Yasouj 75914-353, Iran \\ *Chemistry Department, College of Science, Shahid Chamran University, Ahvaz, Iran \\ Received February 17, 2005
}

Key Words : Aldehydes, Nitriles, Aldoxime, $\mathrm{PCl}_{5}$, Basic alumina

Recently, some chemists found that many reactions proceed efficiently in the solid surfaces. Indeed, in many cases, surfaces of solids have properties that are not duplicated in the solution or gas phase, entirely new chemistry may occur. Even in the absence of new chemistry, a surface reaction may be more desirable than a solution counterpart, because the reaction is more convenient to run, or a high yield of product is attained. For these reasons, synthetic surface organic chemistry is a rapidly growing field of study.

Experiments using these solid phase catalysts generally have the following features; (i) it is often easy to isolate the products and to separate the catalyst; (ii) comparing the reaction conditions with those of related homogeneous reactions, they are so mild that a high yield of specific products and suppression of by-product formation are expected; (iii) selectivity and activity of the catalysts are often comparable to those of enzymes. ${ }^{1}$ Several classes of solids have commonly been used for surface organic chemistry including aluminas, silica gels, and clays. ${ }^{2}$ Basic alumina, the material used commonly for column chromatography, is certainly one of the most interesting of these solids because it has surface properties that suggest a very rich organic chemistry may occur there.

This report describes the efficient application of basic alumina and $\mathrm{PCl}_{5}$ in synthesis of nitriles directly from aldehydes.

Nitriles are of particular interest in preparative organic chemistry due to their rich chemistry. ${ }^{3}$ They serve as useful precursors for the synthesis of amines, carboxylic acids, amides, ketones, and hetrocyclic compounds such as tetrazoles, ${ }^{4}$ thiazoles, ${ }^{5}$ oxazoles, ${ }^{6}$ 2-oxazolines ${ }^{7}$ and 1,2diarylimidazoles. ${ }^{8}$ It has also been well documented that the cyano group itself is present in HIV protease inhibitors, 5lipoxygenase inhibitors, and many other bioactive significant molecules. ${ }^{3 c, d}$ They are usually prepared by nucleophilic substitution with the cyanide anion or by regenerating the cyano group via oxidation, rearrangement, or elimination. ${ }^{3 e}$ The conversion of aldehydes into nitriles is a useful transformation ${ }^{9}$ and a topic of current interest to organic chemists. As a result, a number of reagents have been emerged for this purpose, such as triethylamine sulfurdioxide, ${ }^{10}$ sulphuryl chloride fluoride, ${ }^{11}$ montmorillonite $\mathrm{KSF},{ }^{12}$ formaldehyde, ${ }^{13}$ etc. ${ }^{14}$ However some of these methods suffer from disadvantages such as, preparation of triethylamine sulf uryldioxide and sulphuryl chloride fluoride is inconvenient $\left(-70{ }^{\circ} \mathrm{C}\right)$, dehydration with $\mathrm{KSF}$, zeolite, ${ }^{3 \mathrm{~b}, 14 \mathrm{~b}}$ and envirocat $\mathrm{EPZG}^{14 \mathrm{a}}$ requires high temperature or long reaction times.

Therefore, we reasoned that use of an immobilized system, via the application of solid phase reagents, could lead to a more efficient and cleaner route to these important materials.

Here, we decided to apply an inexpensive and environmentally friendly catalyst, basic alumina, for the preparation of nitriles from aldehydes in one pot without solvents (Scheme 1).

Alumina $/ \mathrm{PCl}_{5}$ was shown to have a remarkably high activity for the conversion of alkyl, aryl and heterocyclic aldehydes into nitriles in high yields, without any of the environmental disadvantages of using toxic solvents. In a typical experiment, aldehyde, alumina, hydroxylamine hydrochloride and phosphorus pentachloride $\left(\mathrm{PCl}_{5}\right)$ were mixed thoroughly. The mixture was heated in an oil bath at $120^{\circ} \mathrm{C}$ without use of any solvents for the appropriate time (Table 1). The products obtained were analyzed by IR, and NMR spectroscopy, and by direct comparison with authentic samples. ${ }^{14-16}$

The mechanism of the reaction could be briefly proposed

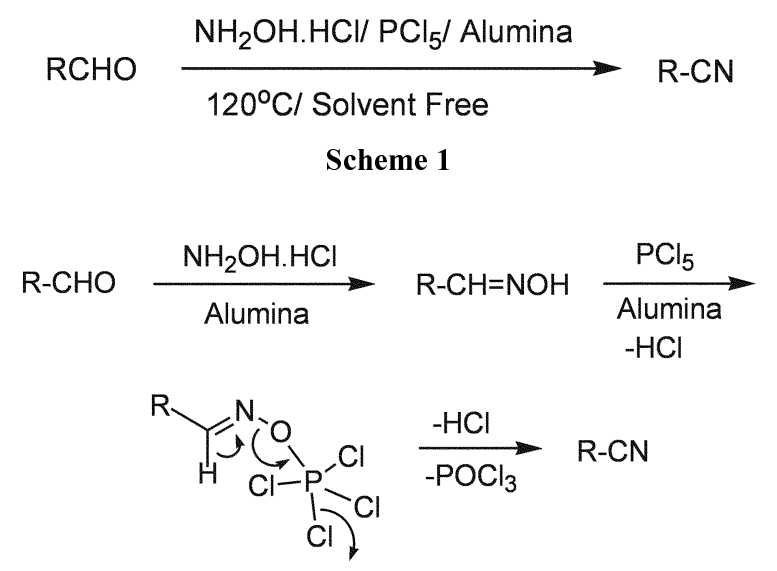

Scheme 2 
Table 1. One-pot conversion of aldehydes into corresponding nitriles in the presence of basic alumina with $\mathrm{PCl}_{5}$ at $120{ }^{\circ} \mathrm{C}$ in an oil bath. ${ }^{a, b}$

\begin{tabular}{|c|c|c|c|}
\hline Entry & Substrate & Product & $\begin{array}{l}\text { Time Yield } \\
(\min .)(\%)\end{array}$ \\
\hline
\end{tabular}

1

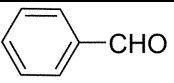

$\square-\mathrm{CN}$

$80 \quad 90 \quad 14 \mathrm{~h}$

2<smiles>O=Cc1ccc(Cl)cc1</smiles><smiles>N#Cc1ccc(Cl)cc1</smiles>

$\begin{array}{lll}67 & 96 & 15\end{array}$

$100 \quad 92 \quad 14 h$

3<smiles>O=Cc1ccccc1O</smiles><smiles>N#Cc1ccccc1O</smiles><smiles>COc1ccc(C=O)cc1</smiles><smiles>COc1ccc(C#N)cc1</smiles>

60 8915<smiles>O=Cc1ccc([N+](=O)[O-])cc1</smiles><smiles>N#Cc1ccc([N+](=O)[O-])cc1</smiles>

$\begin{array}{lll}60 & 91 \quad 15\end{array}$ 6<smiles>O=Cc1cccc([N+](=O)[O-])c1</smiles><smiles>N#Cc1cccc([N+](=O)[O-])c1</smiles>

$60 \quad 88 \quad 14 g$

7<smiles>O=Cc1ccccc1[N+](=O)[O-]</smiles><smiles>N#Cc1ccccc1[N+](=O)[O-]</smiles>

8<smiles>O=CC=Cc1ccccc1</smiles><smiles>N#CC=Cc1ccccc1</smiles>

$75 \quad 96$

$60 \quad 87 \quad 14 h$

9<smiles>O=Cc1cccs1</smiles><smiles>N#Cc1cccs1</smiles><smiles>N#Cc1ccco1</smiles>

$60 \quad 85$ $85 \quad 15$

11<smiles>N#Cc1ccc(C=O)cc1</smiles><smiles>N#Cc1ccc(C#N)cc1</smiles>

75 $89 \quad 16$ 12<smiles>O=Cc1ccc(C=O)cc1</smiles><smiles>N#Cc1ccc(C#N)cc1</smiles>

$\begin{array}{lll}95 & 82 \quad 16\end{array}$

${ }^{a}$ Yields refer to isolated products. ${ }^{b}$ Products were characterized by comparison of their physical data, IR, NMR spectra with known samples.

as follows: the aldehydes were at first converted to aldoximes by reaction with hydroxylamine hydrochloride/ alumina. The aldoximes subsequently undergo rapid dehydration in the presence of alumina/ $\mathrm{PCl}_{5}$ to produce

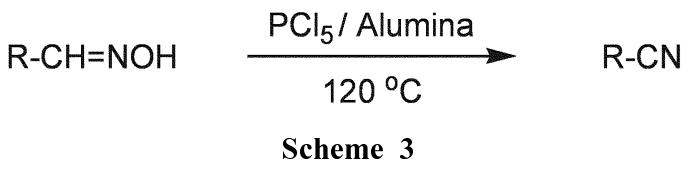

Table 2. Conversion of aldoximes into corresponding nitriles in the presence of basic alumina with $\mathrm{PCl}_{5}$ at $120^{\circ} \mathrm{C}$ in an oil bath. ${ }^{a, b}$

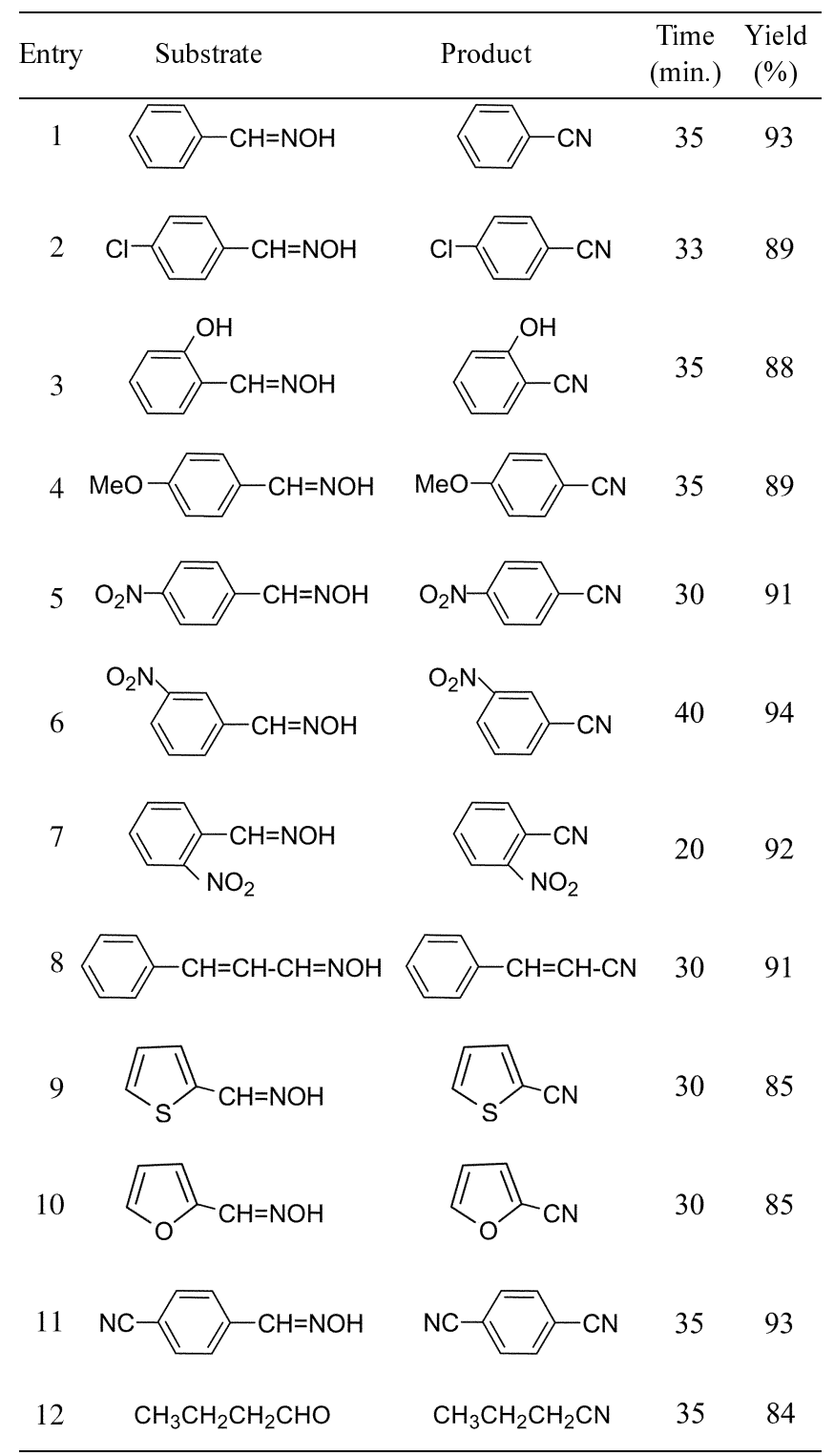

${ }^{a}$ Yields refer to isolated products. ${ }^{b}$ Products were characterized by comparison of their physical data, IR, NMR spectra with known samples.

nitriles (Scheme 2).

The effect of alumina was also evaluated in this reaction. We tried the reaction of benzaldehyde, as a model compound, with $\mathrm{NH}_{2} \mathrm{OH} \cdot \mathrm{HCl} / \mathrm{PCl}_{5}$ without using alumina. The reaction was only partly successful while benzaldehyde was converted into benzonitrile, and also to benzamide as a side product. ${ }^{14 \mathrm{~h}}$ Also, it's important to mention that, the effect of $\mathrm{PCl}_{5}$ was evaluated in this reaction. When the reaction of benzaldehyde with $\mathrm{NH}_{2} \mathrm{OH}$.HCl/alumina without using $\mathrm{PCl}_{5}$ was accomplished in the same way, a mixture of 
benzonitrile and benzaldoxime respectively $1: 3$ was obtained.

Our new method is also useful for the dehydration of various aldoximes to the corresponding nitriles in the presence of alumina/ $\mathrm{PCl}_{5}$ in excellent yields (Scheme 3 ). The results are summarized in Table 2.

In support of proposed mechanism, we examined the

$\mathrm{R}-\mathrm{CHO} \quad \frac{\mathrm{NH}_{2} \mathrm{OH} \cdot \mathrm{HCl}}{\begin{array}{c}\text { Alumina/ } 80^{\circ} \mathrm{C} \\ \text { Sheme } 4\end{array}} \quad \mathrm{R}-\mathrm{CH}=\mathrm{NOH}$

Table 3. Conversion of aldehydes into corresponding aldoximes in the presence of basic alumina with $\mathrm{NH}_{2} \mathrm{OH} . \mathrm{HCl}$ at $80{ }^{\circ} \mathrm{C}$ in an oil bath. ${ }^{a, b}$

Time
(min.) $\begin{gathered}\text { Yield } \\ (\%)\end{gathered}$

${ }^{a}$ Yields refer to isolated products. ${ }^{b}$ Products were characterized by comparison of their physical data, IR, NMR spectra with known samples. reaction of aldehydes with hydroxylamine hydrochloride in the presence of basic alumina to obtain corresponding aldoximes in an oil bath at $80 \mathrm{C}$ (Scheme 4). The results are summarized in Table 3.

In summary, we believe that the present procedure for direct dehydration of aldehydes and also, aldoximes provides an easy, mild, efficient, versatile and general methodology for the preparation of nitriles from different classes of aldehydes or aldoximes, and we feel that it may be a suitable addition to methodologies already present in the literature.

\section{Experimental Section}

General. Basic alumina (Merck, type $150 \mathrm{x}$ ), $\mathrm{PCl}_{5}$ and other chemicals were purchased from Fluka, Merck and Aldrich chemicals companies. The products were characterized by comparing of their spectral (IR, ${ }^{1} \mathrm{H}$ NMR), TLC and physical data with authentic samples.

Conversion of Aldehydes into Nitriles; General Procedure (Table 1). Aldehyde (1 mmol), $\mathrm{NH}_{2} \mathrm{OH} . \mathrm{HCl}$ (0.22 g, $3 \mathrm{mmol}), \mathrm{PCl}_{5}$ (1 mmol, $\left.0.21 \mathrm{~g}\right)$ and alumina $(0.2 \mathrm{~g})$ were thoroughly mixed. The resulting fine powder was transferred to a $5 \mathrm{~mL}$ round-bottom flask and stirred vigorously in an oil bath at $120^{\circ} \mathrm{C}$ for the appropriate time (Table 1). Then ethyl acetate $(10 \mathrm{~mL})$ was added to the mixture and the alumina was removed by filtration. The filtrate was washed with water $(2 \times 10 \mathrm{~mL})$, dried $\left(\mathrm{Na}_{2} \mathrm{SO}_{4}\right)$ and concentrated under reduced pressure to give the crude product, which solids were purified by recrystallization from ethanol and liquids by distillation.

Conversion of Aldoximes into Nitriles; General Procedure (Table 2). A mixture of aldoxime (1 mmol), $\mathrm{PCl}_{5}$ $(1 \mathrm{mmol}, 0.21 \mathrm{~g})$ and alumina $(0.2 \mathrm{~g})$ was heated in an oil bath at $120{ }^{\circ} \mathrm{C}$. The progress of the reaction was monitored by TLC. After the reaction was complete, EtOAc was added to the mixture and the alumina was removed by filtration. It was then washed with water $(2 \times 10 \mathrm{~mL})$, dried $\left(\mathrm{Na}_{2} \mathrm{SO}_{4}\right)$. After removal of the solvent, the crude product was obtained, which solids were purified by recrystallization from ethanol and liquids by distillation.

Conversion of Aldehydes into Aldoximes; General Procedure (Table 3). Aldehyde (1 mmol), $\mathrm{NH}_{2} \mathrm{OH} . \mathrm{HCl}$ $(0.22 \mathrm{~g}, 3 \mathrm{mmol})$ and alumina $(0.2 \mathrm{~g})$ were thoroughly mixed. The mixture was heated in an oil bath at $80^{\circ} \mathrm{C}$. The progress of the reaction was monitored by TLC. After the reaction was complete, ethyl acetate was added to the mixture and the alumina was removed by filtration. It was then washed with $\mathrm{H}_{2} \mathrm{O}(2 \times 10 \mathrm{~mL})$, dried $\left(\mathrm{Na}_{2} \mathrm{SO}_{4}\right)$. The solvent was removed in vaccuo and the crude product was obtained, which was purified by recrystallization from ethanol.

Acknowledgement. Authors acknowledge the partial support of this work by Persian Gulf and Yasouj Universities Research Council. 


\section{References}

1. Pagni, R. M.; Kobalka, G. W.; Boothe, R.; Gaetano, K.; Stewart, L. J.; Canawaya, R. J. Org. Chem. 1998, 63, 4477.

2. For review on surface organic chemistry, see: (a) Posner, G. H. Angew. Chem., Int. Ed. Engl. 1978, 17, 487. (b) McKillop, A.; Young, D. W. Synthesis 1979, 401. (c) Cornelis, A.; Laszlo, P. Synthesis 1985, 909. (d) Laszlo, P. Acc. Chem. Res. 1986, 19, 121. (e) Cornelis, A.; Laszlo, P. In Chemical Reactions in Organic and Inorganic Constrained Systems; Setton, R., Ed.; Reider: Dordrecht, 1986; p 212.

3. (a) Tennant, G. In Comprehensive Organic Chemistry; Barton, D.; Ollis, D. W.; Sutherland, I. O., Eds.; Pergamon Press: Oxford, 1979; Vol. 2, p 528. (b) Srinivas, K. V. N. S.; Bolla Reddy, E.; Das Biswanath Synlett 2002, 625. (c) Lai, G.; Bhamare, N. K.; Anderson, W. K. Synlett 2001, 230. (d) Janakiraman, M. N.; Watenpaugh, K. D.; Tomich, P. K.; Chong, K.-T.; Turner, S. R.; Tommasi, R. A.; Thaisrivongs, S.; Strohbach, J. W. Bioorg. Med. Chem. Lett. 1998, 8, 1237. (e) Kamal, A.; Arifuddin, M.; Rao, V. Synth. Commun. 1998, 28, 4507.

4. (a) Wittenberger, S. J.; Donner, B. G. J. Org. Chem. 1993, 58, 4139. (b) Bailey, T. R.; Diana, G. D.; Kowalczyk, P. J.; Akullian, V.; Eissenstat, M. A.; Cutcliffe, D.; Mallamo, J. P.; Carabateas, P. M.; Pevear, D. C. J. Med. Chem. 1992, 35, 4628. (c) Kadaba, P. K. Synthesis 1973, 71.

5. (a) Gu, X.-H.; Wan, X.-Z.; Jiang, B. Bioorg. Med. Chem. Lett. 1999, 9, 569. (b) Chihiro, M.; Nagamoto, H.; Tekemura, I.; Kitano, K.; Komatsu, H.; Sekiguchi, K.; Tabusa, F.; Mori, T.;
Tominaga, M.; Yabuuchi, Y. J. Med. Chem. 1995, 38, 353

6. (a) Moody, C. J.; Doyle, K. J. Prog. Heterocyclic Chem. 1997, 9 , 1. (b) Ducept, P. C.; Marsden, S. P. Synlett 2000, 692.

7. Jnaneshwara, G. K.; Deshpande, V. H.; Lalithambika, M.; Ravindranathan, T.; Bedekar, A. V. Tetrahedron Lett. 1998, 39 459.

8. Fabiani, M. E. Drug News Perspect. 1999, 12, 207.

9. (a) Friedrich, K.; Wallenfels, K. In The Chemistry of the Cyno Group; Rappoport, Z., Ed.; Interscince: New York, 1970; pp 92 93. (b) Foley, P. J. J. Org. Chem. 1969, 34, 2805.

10. Olah, G. A.; Vankar, Y. D. Synthesis 1978, 702.

11. Olah, G. A.; Narang, S. C.; Garcia, L. A. Synthesis 1980, 659.

12. Meshram, H. M. Synthesis 1992, 943.

13. Ali, S. L.; Nikalje, M. D.; Dewkar, G. K.; Paraskar, A. S.; Sudalai, A. J. Chem. Res. (S) 2000, 30.

14. (a) Bandgar, B. P.; Jagtap, S. R.; Ghodeshwar, S. B.; Wadgaonkar, P. P. Synth. Commun. 1995, 25(19), 2993. (b) Narayan Rao, M.; Kumar, P.; Garyali, K. Org. Prep. Proceed. Int. 1989, 21, 230. (c) Miller, C. P.; Kaufman, D. H. Synlett 2000, 8, 1169. (d) Bavendal, I. R.; Ley, S. V.; Sneddon, H. F. Synlett 2002, 5, 775. (e) Yadav, J. S.; Subba Reddy, B. V.; Madan, Ch. J. Chem. Res. (S) 2001, 190. (f) McAllister, G. D.; Wilfred, C. D.; Taylor, R. J. K. Synlett 2002, 8, 129. (g) Sharghi, H.; Sarvari, M. H. Tetrahedron 2002, 58, 10323. (h) Sharghi, H.; Sarvari, M. H. Synthesis 2003, 243.

15. Kumar, S. H. M.; Reddy, B. V.; Reddy, P. T.; Yadav, J. S. Synthesis 1999, 586

16. Carotti, A.; Campagna, F. Synthesis 1979, 56. 